puscles of animal origin had been found in air which had been vitiated from certain sources, and how by means of the discovery the sources of evil were detected and hence done away with. Dr. Bartlett holds a strong opinion against the probability of finding specific disease germs in any form by which our present powers of observation can recognise them, but he is equally impressed with the indications afforded by the results of some of his experiments as to the noxious influence of animal organisms, including, perhaps, the specific matter of the various contagia and of tubercle, which are often contained in impure air.

Capt. R. T. Hildyard drew attention to the influence for good which might be exerted by medical men if, in the course of their private practice, they had more regard to the sanitary conditions under which their patients were living.- The Hon. J. A. R. Russell brought gether a large amount of carefully-prepared meteorological and other statistics to show how climate improved with slight elevation. In a series of conclusions to which his observations had led, he pointed out how the ranges of temperature, yearly, monthly, and diurnal, were less at certain elevations than in lower sites, and he regarded it most desirable that every house should be built on arches or on piers admitting of ventilation above the ground level, and that in country districts no house should be considered habitable of which the floor is on a level with or below the ground.-Miss Yates, Hon. Sec. to the Bread Reform League, pointed out the advantages of wheat-meal bread over white bread, both as regards its nutritive properties and otherwise, and urged its general use as a means of promoting national health, especially amongst the classes depending on bread as their main article of food.

\section{ON THE PERCEPTION OF COLOURS BY THE} ANCIENT MAORIS

$\mathrm{I} \mathrm{N}$ an interesting paper on this subject by $\mathrm{Mr}$. Colenso, he gives a great deal of information on this subject, derived from his individual experience during a very long period of dwelling among the Maoris, and that before the country was settled, and by his having travelled very much among them, frequently in parts where no white man had ever been, sometimes on the battle-field, both during and after the fight, ever with them as medical man, often in the confidence of their best head men. The colours of black, white, red and brown were the prized and favourite ones. The purer states, especially of each of these colours were highly valued, to which may be arlded green and yellow. These several colours and their varying hues comprised nearly all that pertained to their dresses and personal decorations, to their principal houses and canoes. In the olden times a chief's house might truly be called a house "of many colours," which were artistically and laboriously displayed. Each tint or shade of colour bore its own peculiar name plainly and naturally, or figuratively sometimes both. They possessed a fine general discrimination of the various shades and hues and tints; they could give an accurate description of a rainbow, of all its various colours; they noticed the iridescent hues of the feathers of a pigeon's neck, of some shells, and the delicate evanescent tints on the ventral surfaces of many fish. From their general hues alone the Maoris could accurately tell whether far off and to them unknown districts were covered with a vegetation of fern or flax (Phormium) or grasses, but far above all their fine discrimination of delicate hues and shades was correctly shown in their nice distinction of the various tints of the flesh of the several kinds of kumara and taro. Once travelling on the coast, nearly forty years ago, Colenso mel an old chief who told him that long ago he had cultivated a variety of the taro, which is called Wairuaarangi, but that it had long been lost. Knowing this sort from having met it in the north, and remembering the delicate and curious pink colour, Colenso tested the knowledge of the chief by asking what colour it was, which he immediately minutely described. They had early succeeded in getting brilliant black and red dyes. The old Maoris had a peculiar bias towards neutral colours. Blue was certainly known to them, and they obtained it from two sources, one mineral, the other vegetable; and they had even distinct names for several shades of blue. Throughout this paper Mr. Colenso criticises and contradicts many of the assertions made by Mr. Stack, from probably an insufficient knowledge of Maori, in a memoir recently published on the colour-sense of the Maoris (Trans. New Zealand Institute, vol. xiv. p. 49).

\section{FRIEDRICH WÖHLER}

WOHLER is dead. A man, who was born four years after Priestley died, who worked with Berzelius, who was engaged in chemical research when the brilliant genius of Davy was ranging over the whole field of chemical phenomena, who was contemporaneous witb Liebig and Graham-this man has but now passed away from our midst.

Wöhler witnessed, and well bore his part in helping on the many great advances which chemistry has made since the science was founded by Black, Priestley, and Lavoisier.

Friedrich Wöhler was born in I 800 near Frankfurt; he graduated as Doctor of Medicine at Heidelberg in I823, but in place of pursuing the study of the uncertain art of medicine, as he tells us in his "Reminiscences," he determined to devote himself to the more exact science of chemistry. Recommended to Berzelius by Gmelin, Wöhler spent the winter of $1823-4$ in the laboratory of the great Swedish chemist.

As we read the Reminiscences of Wöhler's youth-published a few years ago in the Berichte of the Berlin Chemical Society-we are ready to exclaim that it was impossible that, with the appliances which he had at his command, Berzelius could accomplish chemical work of any value. A few tables, an oil lamp or two, a large jar of water, basins and flasks - that was nearly all. The ancient Anna cooked in the kitchen, where also stood the sand-bath and the rarely-used furnace; Anna still spoke in these days of "oxidised marine acid gas;" but Berzelius was beginning to think that it might be better to say chlorine.

Five years later we come to a date memorable in the history of chemistry. Hitherto it had seemed as if the boundary which chemists had found it convenient to draw between organic and inorganic chemistry had a real existence in nature ; but Wöhler's preparation of urea, in I828, from constituents of mineral origin, showed that this chemical boundary was as unreal as any other drawn by the too ardent devotees of system; and that, as Graham said, in nature "distinctions of class are never absolute." The artificial barrier broken down, the living science of the chemistry of carbon compounds rapidly grew and overspread the place where the dead wall had been. Wöhler's discovery seemed a small one at the time, but what great fruit has it borne :

\section{"Walls adnit of no expansion, Trellis work may haply flower Twice the size."}

About this time (1830) the reaction led by Dumas against the Berzelian system of classification was growing in strength; in their zeal to overthrow the evils which had arisen from the axiom of the Swedish chemist-that every compound must be built up of two electrically opposed parts-chemists had sought likewise to demolish the conception of compound radicles, which formed so marked a feature of the Berzelian system. 